University of Nebraska - Lincoln

DigitalCommons@University of Nebraska - Lincoln

Agronomy \& Horticulture - Faculty Publications

Agronomy and Horticulture Department

2-27-2001

\title{
Glyphosate-Resistant Soybean Cultivar Response to Glyphosate
}

Roger Wesley Elmore

University of Nebraska-Lincoln, roger.elmore@unl.edu

Fred W. Roeth

University of Nebraska-Lincoln, fwroeth41@gmail.com

Robert N. Klein

Univ. of Nebraska-Lincoln, West Central Res. and Ext. Center, North Platte, NE, robert.klein@unl.edu

Stevan Z. Knezevic

Univ. of Nebraska, Northeast Res. and Ext. Center-Haskell Ag Lab, Concord, NE, sknezevic2@unl.edu

Alex Martin

University of Nebraska-Lincoln, amartin2@unl.edu

See next page for additional authors

Follow this and additional works at: https://digitalcommons.unl.edu/agronomyfacpub

Part of the Plant Sciences Commons

Elmore, Roger Wesley; Roeth, Fred W.; Klein, Robert N.; Knezevic, Stevan Z.; Martin, Alex; Nelson, Lenis Alton; and Shapiro, Charles A., "Glyphosate-Resistant Soybean Cultivar Response to Glyphosate" (2001). Agronomy \& Horticulture -- Faculty Publications. 30.

https://digitalcommons.unl.edu/agronomyfacpub/30

This Article is brought to you for free and open access by the Agronomy and Horticulture Department at DigitalCommons@University of Nebraska - Lincoln. It has been accepted for inclusion in Agronomy \& Horticulture -Faculty Publications by an authorized administrator of DigitalCommons@University of Nebraska - Lincoln. 


\section{Authors}

Roger Wesley Elmore, Fred W. Roeth, Robert N. Klein, Stevan Z. Knezevic, Alex Martin, Lenis Alton Nelson, and Charles A. Shapiro 


\title{
Glyphosate-Resistant Soybean Cultivar Response to Glyphosate
}

\author{
Roger W. Elmore,* Fred W. Roeth, Robert N. Klein, Stevan Z. Knezevic, Alex Martin, \\ Lenis A. Nelson, and Charles A. Shapiro
}

\begin{abstract}
Glyphosate ( $N$-(phosphonomethyl) glycine)-resistant (GR) soybean [Glycine $\max (\mathrm{L}$.) Merr.] technology is gaining acceptance in U.S. cropping systems, yet potential yield suppression from either cultivar genetic differentials, the GR gene/gene insertion process, or glyphosate is a concern. Other work shows that the GR gene/gene insertion process may suppress soybean yield. No one has reported the effects of glyphosate on a diverse group of commercially available GR soybean cultivars. In this study we evaluated one of the potential sources of GR yield suppression-the effect of glyphosate on yield, growth, and development of GR cultivars. Field experiments were conducted at four Nebraska locations with12 GR cultivars in 1998 and 13 GR cultivars in 1999. Soybean response to glyphosate, ammonium sulfate (AMS), and water application at 21 and $42 \mathrm{~d}$ after soybean emergence was compared with control plots treated with AMS and water in 1998. An additional control, water alone, was added in 1999. Grain yield among cultivars differed as expected with a range of 3.44 to $3.96 \mathrm{Mg} \mathrm{ha}^{-1}$ in the 2-yr averages. Glyphosate did not affect the majority of the soybean growth and development characteristics measured. Grain yield of GR soybean was not affected by glyphosate at any location or when averaged over locations. Two-year average grain yield of cultivars treated with glyphosate, AMS, and water was 3.74 $\mathrm{Mg} \mathrm{ha}^{-1}$; this was not different from 3.79 $\mathrm{Mg} \mathrm{ha}^{-1}$ with AMS and water treatment.
\end{abstract}

$\mathrm{T}$ HE development of herbicide-resistant crops represents new weed control technology. Examples include soybean, corn (Zea mays L.), and canola (Brassica napus L.) resistant to glyphosate, the active ingredient of Roundup, and glufosinate (2-amino-4-(hydroxymethylphosphinyl)butanoic acid) (Moll, 1997; Rasche and Gadsby, 1997). Glyphosate-resistant (GR) soybean was one of the first major applications of genetic engineering in field crops (Delannay et al., 1995; Padgette et al., 1995). Growers have readily integrated herbicide-resistant crops into their production practices. Herbicideresistant soybean were grown on $7,17,44$, and $57 \%$ of the U.S. soybean area from 1996 to 1999, respectively (USDA, 1999; National Agric. Statistics Service, 1999). Most herbicide-resistant soybean cultivars are GR.

Although GR technology is gaining acceptance in U.S. cropping systems, potential yield suppression associated with GR cultivars is a concern of producers and seed companies. Data from university soybean cultivar performance trials in several states suggest yield sup-

R.W. Elmore and F.W. Roeth, Univ. of Nebraska, South Central Res. and Ext. Center, Clay Center, NE 68933; L.A. Nelson and A. Martin, Dep. of Agronomy, Univ. of Nebraska, Lincoln, NE 68583; R.N. Klein, Univ. of Nebraska-Lincoln, West Central Res. and Ext. Center, North Platte, NE 69101; and C.A. Shapiro and S.Z. Knezevic, Univ. of Nebraska, Northeast Res. and Ext. Center-Haskell Ag Lab, Concord, NE 68728. Univ. of Nebraska-Lincoln, Agric. Res. Div. J. Ser. no. 13032. Received 30 May 2000. *Corresponding author (relmore1 @unl.edu).

Published in Agron. J. 93:404-407 (2001). pression may exist (Nelson et al., 1997, 1998, 1999; Minor, 1998; Oplinger et al., 1998; Harry Minor, Univ. of Missouri, personal communication, 1999).

Yield suppression may result from either (i) cultivar genetic differentials, (ii) the GR gene/gene insertion process (GR effect), or (iii) glyphosate (herbicide effect), or a combination of the three. Thus, in the first situation yield of GR cultivars may be suppressed relative to that of other cultivars simply because the GR gene was inserted in low yielding or older cultivars. We consider yield suppression associated with the GR effect or herbicide effect a greater potential problem than cultivar genetic differentials since the latter can be overcome by inserting the GR gene in high yielding parent lines. The relative importance of yield suppression due to cultivar genetic differentials should thus diminish with time. The GR effect and herbicide effect, however, could potentially handicap yields regardless of the cultivars used. Elmore et al. (2001) found that GR lines yielded $5 \%$ less than their non-GR sister lines. This documented that at least part of the yield suppression associated with GR soybean is the GR gene or its insertion.

Research with the first GR line, 40-3-2 and its progeny indicated that GR agronomic characteristics and yield were not affected by glyphosate applications up to twice the labeled rate $\left[1.68 \mathrm{~kg}\right.$ a.e. (acid equivalent) $\mathrm{ha}^{-1}$ ] (Delannay et al., 1995). Glyphosate application in both vegetative and reproductive stages of the crop did not adversely affect the crop and the GR gene was stable over successive generations. The GR gene from 40-3-2 remains as the source for tolerance in current GR soybean cultivars (X. Delannay, personal communication, Dec. 1999).

Glyphosate-resistant soybean treated with glyphosate have yielded the same or better than GR soybean treated with conventional pre- or postemergence herbicides (Bennett et al., 1998; Hofer et al., 1998; Nelson and Renner, 1999). Observations of side-by-side comparisons in 1997 at the University of Nebraska South Central Research and Extension Center (SCREC) indicated that glyphosate with AMS (ammonium sulfate) may have delayed soybean flowering (R.W. Elmore, unpublished data, 1997). Ammonium sulfate enhances glyphosate activity and weed control. Nelson and Renner (1999) found that glyphosate with and without AMS resulted in similar yields and weed control with a single cultivar. No one has reported the effects of glyphosate

\footnotetext{
Abbreviations: a.e., acid equivalent; AMS, ammonium sulfate; DAE, days after emergence; Gly, glyphosate; GR, glyphosate resistant; NEREC-HAL, Northeast Research and Extension Center-Haskell Agric. Lab.; R1, flowering; R7, physiological maturity; R8, harvest maturity; SCREC, South Central Research and Extension Center; WCREC, West Central Research and Extension Center.
} 
Table 1. Information pertinent to experiments conducted in Nebraska, 1998-1999.

\begin{tabular}{|c|c|c|c|c|c|c|c|}
\hline Location & City & Year & $\begin{array}{l}\text { Planting } \\
\text { date }\end{array}$ & $\begin{array}{c}\text { Emergence } \\
\text { date }\end{array}$ & $\begin{array}{l}\text { Irrigation } \\
\text { applied }\end{array}$ & Rainfall & $\begin{array}{c}\text { Harvest } \\
\text { date }\end{array}$ \\
\hline Agronomy Farm & Lincoln & $\begin{array}{l}1998 \\
1999\end{array}$ & $\begin{array}{l}25 \text { May } \\
25 \text { May }\end{array}$ & $\begin{array}{l}1 \text { June } \\
1 \text { June }\end{array}$ & $\begin{array}{l}\text { none } \\
\text { none }\end{array}$ & $\begin{array}{l}299 \\
268\end{array}$ & $\begin{array}{l}20 \text { Oct. } \\
22 \text { Oct. }\end{array}$ \\
\hline NEREC-HAL $\dagger$ & Concord & $\begin{array}{l}1998 \\
1999\end{array}$ & $\begin{array}{l}27 \text { May } \\
26 \text { May }\end{array}$ & $\begin{array}{l}3 \text { June } \\
3 \text { June }\end{array}$ & $\begin{array}{r}40 \\
102\end{array}$ & $\begin{array}{l}421 \\
306\end{array}$ & $\begin{array}{l}23 \text { Oct. } \\
14 \text { Oct. }\end{array}$ \\
\hline SCREC & Clay Center & $\begin{array}{l}1998 \\
1999\end{array}$ & $\begin{array}{l}20 \text { May } \\
26 \text { May }\end{array}$ & $\begin{array}{l}1 \text { June } \\
5 \text { June }\end{array}$ & $\begin{array}{l}127 \\
233\end{array}$ & $\begin{array}{l}144 \\
341\end{array}$ & $\begin{array}{l}13 \text { Oct. } \\
16 \text { and } 22 \text { Oct. }\end{array}$ \\
\hline WCREC\$ & North Platte & $\begin{array}{l}1998 \\
1999\end{array}$ & $\begin{array}{l}26 \text { May } \\
25 \text { May }\end{array}$ & $\begin{array}{l}1 \text { June } \\
2 \text { June }\end{array}$ & $\begin{array}{l}3 \text { applications in both years; } \\
\text { amounts not recorded }\end{array}$ & $\begin{array}{l}375 \\
411\end{array}$ & $\begin{array}{l}13 \text { Oct. } \\
15 \text { Oct. }\end{array}$ \\
\hline
\end{tabular}

$\uparrow$ Northeast Research and Extension Center-Haskell Ag Lab.

+ Univ. of Nebraska South Central Research and Extension Center.

$\S$ West Central Research and Extension Center.

relative to controls without glyphosate on a diverse group of commercially available GR cultivars.

We designed experiments to test for two possible sources of yield suppression: the effect of glyphosate herbicide application on GR soybean (herbicide effect, reported in this paper) and the effect of the GR gene insertion event (GR effect, see Elmore et al., 2001). Field experiments were conducted at four Nebraska locations with the intent to compare the effects of glyphosate with AMS and water to AMS with water on 12 cultivars in 1998. An additional cultivar and a control treatment of water only were added in 1999.

\section{MATERIALS AND METHODS}

Field experiments were conducted at four Nebraska locations in 1998 and 1999 (Table 1). Soils at the respective sites were: Agronomy Farm: Kennebec silt loam (fine-silty, mixed, mesic, Cumilic Hapludolls); Northeast Research and Extension Center-Haskell Ag Lab (NEREC-HAL): Alcester silty clay loam (fine-silty, mixed, mesic, Cumulic Haplustolls); South Central Research and Extension Center (SCREC): Hastings silt loam (fine, montmorillonitic, mesic Udic Argiustoll); and West Central Research and Extension Center (WCREC): Cozad and Hord silt loam (coarse-silty, mixed, mesic Fluventic Haplustolls and fine-silty, mixed, mesic Cumulic Haplustolls). Previous crop in both years at all locations was corn. Subplots consisted of four rows $0.76 \mathrm{~m}$ wide by $9.1 \mathrm{~m}$ in length. Seeding rate was 370000 seed $\mathrm{ha}^{-1}$. Field preparation activities are

Table 2. Herbicide application information by location and year. Nebraska, 1998-1999 (see Table 1 for location abbreviations).

\begin{tabular}{|c|c|c|c|c|}
\hline Location & Year & $\begin{array}{c}\text { Preemergence } \\
\text { treatment } \dagger\end{array}$ & $\begin{array}{l}\text { 1st glyphosate } \\
\text { application } \div\end{array}$ & $\begin{array}{c}\text { 2nd glyphosate } \\
\text { application } \div\end{array}$ \\
\hline Agronomy Farm & 1998 & 24 May & 1 July & 28 July \\
\hline Agronomy Farm & 1999 & 24 May & 25 June & 10 July \\
\hline NËREC§ & 1998 & 27 May & 1 July & 16 July \\
\hline NEREC§ & 1999 & 27 May & 24 June & 14 July \\
\hline SCREC & 1998 & 21 May & 29 June & 13 July \\
\hline SCREC & 1999 & 26 May & 25 June & 19 July \\
\hline WCREC & 1998 & 26 MayII & 29 June & 20 July \\
\hline WCREC & 1999 & 25 May + & 23 June & 16 July \\
\hline
\end{tabular}

$\dagger$ Metolachlor (2-chloro- $N$-(2-ethyl-6-methylphenyl)- $N$-(2-methoxy-1-methyl ethyl)acetamide; $\left.2.32 \mathrm{~kg}^{\mathrm{a} . \mathrm{i} .} \mathrm{ha}^{-1}\right)$.

+0.84 kg a.e. ha ${ }^{-1}$.

$\S$ Clethodim, $(\boldsymbol{E}, \boldsymbol{E})-( \pm)-2-[1-[[(3-c h l o r o-2-p r o p e n y l) o x y]$ imino $]$ propyl]5-[2-(ethylthio)propyl]-3-hydroxy-2-cyclohexen-1-one, at $0.11 \mathrm{~kg} \mathrm{ha}^{-1}$ and crop oil concentrate at $1.2 \mathrm{~L} \mathrm{ha}^{-1}$ was applied on 25 June 1998 and 6 July 1999 for volunteer corn control.

II Metolachlor (1.8 kg a.i. ha $\left.{ }^{-1}\right)$ and metribuzin $\left(0.41 \mathrm{~kg}\right.$ a.i. $\left.\mathrm{ha}^{-1}\right)$. tf $s$-metolachlor, $1.4 \mathrm{~kg}$ a.i. $\mathrm{ha}^{-1}$. as follows: Agronomy farm 1998 and 1999-disk and field cultivate in spring; NEREC-HAL 1998 - disk and field cultivate in spring 1999-fall disk, spring disk and field cultivate; SCREC 1998-two passes of Mulch Master (John Deere, Moline, IL) in spring 1999-rototilled in spring; WCREC: 1998 and 1999-ridge till.

Spray treatments were applied topically to the soybean about 21 and $42 \mathrm{~d}$ after emergence (Table 2). Soybean growth stages for the first and second glyphosate applications were V2 to V5 and R1 to R3, respectively (Ritchie et al., 1996). Weather conditions were near normal both pre- and posttreatment at all locations. Treatments consisted of glyphosate at $0.84 \mathrm{~kg}$ a.e. $\mathrm{ha}^{-1}$ plus AMS at $2.7 \mathrm{~kg}$ a.i. $\mathrm{ha}^{-1}$ in water, and AMS at $2.7 \mathrm{~kg} \mathrm{ha}^{-1}$ in water. Spray volumes of $187 \mathrm{~L} \mathrm{ha}^{-1}$ were achieved with 8002 spray tips on tractor-mounted, compressed air sprayers. Plots other than those at WCREC were sprayed with the preemergence herbicide combination of metolachlor (2-chloro- $N$-(2-ethyl-6-methylphenyl)- $N$-(2-methoxy-1-methylethyl)acetamide; $2.32 \mathrm{~kg}$ a.i. $\mathrm{ha}^{-1}$ ) and metribuzin (4-amino6-(1,1-dimethylethyl)-3-(methylthio)-1,2,4-triazin-5(4H)-one; $0.51 \mathrm{~kg}$ a.i. $\left.\mathrm{ha}^{-1}\right)$. At WCREC plots were sprayed with the preemergence herbicide combination of metolachlor $(1.8 \mathrm{~kg}$ a.i. ha $\left.{ }^{-1}\right)$, metribuzin $\left(0.41 \mathrm{~kg}\right.$ a.i. ha $\left.{ }^{-1}\right)$, and glyphosate $(0.84$ $\mathrm{kg}$ a.e. $\left.\mathrm{ha}^{-1}\right)$ in 1998. In 1999 , s-metolachlor $\left(1.4 \mathrm{~kg}\right.$ a.i. ha $\left.{ }^{-1}\right)$ was used preemergence at WCREC. The experiments were maintained weed-free by hand weeding.

A split-plot, randomized complete block experimental design was used with a factorial arrangement of treatments. Twelve GR soybean cultivars were included in 1998 and 13 GR cultivars were included in 1999 (Table 3). Cultivars with maturities adapted to all four locations were provided by some of the major seed companies in Nebraska. Each cultivar (main plot) was planted in two (1998) or three (1999) adjacent sub-

Table 3. Glyphosate-resistant soybean cultivars used in this study. Nebraska, 1998-1999.

\begin{tabular}{lllc}
\hline Cultivar no. & \multicolumn{1}{c}{ Company } & $\begin{array}{c}\text { Glyphosate-resistant } \\
\text { cultivars }\end{array}$ & $\begin{array}{c}\text { Maturity } \\
\text { group }\end{array}$ \\
\hline $\mathbf{1}$ & Golden Harvest & H1280RR & 2.9 \\
$\mathbf{2}$ & Golden Harvest & H1357RR & $\mathbf{3 . 5}$ \\
$\mathbf{3}$ & Pioneer & $\mathbf{9 2 B 0 5}$ & $\mathbf{2 . 0}$ \\
$\mathbf{4}$ & Pioneer & $\mathbf{9 2 B 5 1}$ & $\mathbf{2 . 5}$ \\
$\mathbf{5}$ & Asgrow & $\mathbf{A G 2 7 0 2}$ & $\mathbf{2 . 7}$ \\
$\mathbf{6}$ & Asgrow & Ag3002 & $\mathbf{3 . 0}$ \\
$\mathbf{7}$ & Northrup King & $\mathbf{S 2 8 V 8}$ & $\mathbf{2 . 8}$ \\
$\mathbf{9}$ & Northrup King & $\mathbf{S 3 5 F 5}$ & $\mathbf{3 . 5}$ \\
$\mathbf{1 0}$ & NU Pride-Excel & $\mathbf{8 3 5 5}$ & $\mathbf{3 . 5}$ \\
$\mathbf{1 1}$ & Dyna Gro & $\mathbf{1 8 7}$ & $\mathbf{2 . 5}$ \\
$\mathbf{1 2}$ & Asgrow & A3601STS/RR & $\mathbf{3 . 5}$ \\
$\mathbf{1 3}$ (1999 only) & NC+ & $\mathbf{3 2 R R}$ & $\mathbf{3 . 2}$ \\
\hline
\end{tabular}


Table 4. Spray treatment effects on grain yield and other plant characteristics. Nebraska, 1998-1999.

\begin{tabular}{|c|c|c|c|c|c|c|c|c|c|}
\hline \multirow[b]{2}{*}{$\begin{array}{l}\text { Spray } \\
\text { treatment }\end{array}$} & \multicolumn{2}{|c|}{ Grain yield } & \multicolumn{2}{|c|}{ Flowering date } & \multicolumn{2}{|c|}{ Physiological maturity } & \multicolumn{2}{|c|}{ Mature plant height } & \multirow{2}{*}{ 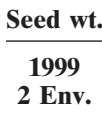 } \\
\hline & $\begin{array}{c}\text { 1998-1999 } \\
8 \text { Env. }{ }^{\dagger}\end{array}$ & $\begin{array}{c}1999 \\
4 \text { Env. }\end{array}$ & $\begin{array}{c}\text { 1998-1999 } \\
6 \text { Env. }\end{array}$ & $\begin{array}{c}1999 \\
4 \text { Env. }\end{array}$ & $\begin{array}{c}\text { 1998-1999 } \\
7 \text { Env. }\end{array}$ & $\begin{array}{c}1999 \\
4 \text { Env. }\end{array}$ & $\begin{array}{c}\text { 1998-1999 } \\
8 \text { Env. }\end{array}$ & $\begin{array}{c}1999 \\
4 \text { Env. }\end{array}$ & \\
\hline & \multicolumn{2}{|c|}{$\longrightarrow \mathrm{Mg} \mathrm{ha}^{-1}$} & \multicolumn{2}{|c|}{ — d from 31 May — } & \multicolumn{2}{|c|}{ — d from 31 May — } & \multicolumn{2}{|c|}{$\longrightarrow \mathrm{mm}$} & $\mathrm{g} / \mathbf{1 0 0}$ \\
\hline Gly & 3.74* & 3.65 & 57 & 54 & 112 & 112 & 963 & 986b & $14.6 a$ \\
\hline AMS & 3.79 & 3.73 & 57 & 54 & 112 & 112 & 969 & 994a & $14.4 \mathrm{~b}$ \\
\hline Water & - & 3.70 & - & 54 & - & 112 & - & 995a & 14.6a \\
\hline SE & 0.16 & 0.03 & 16 & 0.1 & 2 & 0.2 & 3 & 3 & 0.1 \\
\hline
\end{tabular}

* Means within the same column followed by the same letters or without letters are not different $(p \leq 0.05)$.

$\dagger$ Env. = Total environments (locations $\times$ years) where data were collected.

$\ddagger$ Spray treatments: Gly $=$ glyphosate with ammonium sulfate (AMS) and water; AMS $=$ AMS and water; Water $=$ water alone.

plots (spray treatments) in four replicates. In 1998, one subplot was sprayed with glyphosate, AMS, and water, and the second subplot was sprayed with AMS and water. In 1999, a control treatment of water only was also included as a third subplot.

Crop development and plant height were monitored at 21, 42, and 56 days after emergence (DAE), and dates of flowering (R1), physiological maturity (R7), and harvest maturity (R8) were recorded (Ritchie et al., 1996). In addition, plant counts were taken during the vegetative stages and lodging scores were recorded at R8. The center two rows of each plot were harvested with a small plot harvester for yield and seed weight determination. Grain yield was adjusted to $130 \mathrm{~g} \mathrm{~kg}^{-1}$ moisture content.

Data were processed using SAS mixed models procedures (Littell et al., 1996). Cultivar and spray treatments were considered fixed effects. Locations, replicates, and their interactions with the fixed effects were considered random effects. Single degree-of-freedom comparisons were used to isolate the main effect of spray treatments in both years. Pair-wise comparisons of cultivar-spray treatment interactions were generated using the PDIFF option of the Least Squares Means statement of PROC Mixed in all analyses (Littell et al., 1996). Two sets of analyses were used for each variable because all cultivars and treatments were not included in both years. The first compared the first 12 cultivars and two spray treatments (glyphosate with AMS and water vs. AMS and water) over both years. The second analyses compared all 13 cultivars over all three spray treatments (glyphosate with AMS and water, AMS and water, and water alone) in 1999. All data presented are least squares adjusted means. Differences are significant at $P \leq 0.05$.

\section{RESULTS AND DISCUSSION}

\section{Cultivar Effects}

Many characteristics differed among cultivars when averaged over locations. These included plant height at 42 and 56 DAE, and growth stage at 56 DAE for 1999 (data not shown). These findings are common when cultivars from different seed companies and of different maturities are compared in experiments (Nelson et al., 1997, 1998, 1999).

Some cultivar characteristics were also affected by the location at which the cultivar was grown. These included seed yield, plant height at $21 \mathrm{DAE}$, flowering date, plant height at flowering, date of physiological maturity, date of harvest maturity, and lodging in 1999 , and growth stage at $42 \mathrm{DAE}$ and plant height at 56 DAE in the 2-yr data (data not shown). Again, differences among cultivars and locations are common when diverse cultivars are compared.

\section{Spray Treatment Effects}

Neither glyphosate nor AMS affected grain yield or the majority of the soybean growth and development characteristics measured (Table 4). We saw no significant visual injury. This confirms the grain yield data of Nelson and Renner (1999) with a single cultivar, but contradicts earlier observations of side-by-side compari-

Table 5. Spray treatment effects on glyphosate-resistant soybean cultivars. Averages of four locations. Nebraska, 1999.

\begin{tabular}{|c|c|c|c|c|c|c|}
\hline \multirow[b]{3}{*}{ Cultivar $\dagger$} & \multicolumn{6}{|c|}{1999 data } \\
\hline & \multicolumn{3}{|c|}{ Yield } & \multicolumn{3}{|c|}{ Physiological maturity } \\
\hline & Gly & AMS & Water & Gly & AMS & Water \\
\hline & \multicolumn{3}{|c|}{$\mathrm{Mg} \mathrm{ha}^{-1}$} & \multicolumn{3}{|c|}{ d from 31 May } \\
\hline $\mathbf{1}$ & $3.76^{*}$ & 3.92 & 3.69 & 115 & 115 & 115 \\
\hline 2 & 3.76 & 3.78 & 3.79 & 110 & 110 & 110 \\
\hline 3 & 3.33 & 3.42 & 3.44 & 118 & 118 & 118 \\
\hline 4 & 3.63 & 3.58 & 3.46 & 102 & 102 & 102 \\
\hline 5 & 3.67 & 3.91 & 3.85 & 106 & 106 & 106 \\
\hline 6 & 3.75 & 3.77 & 3.76 & 111 & 111 & 111 \\
\hline 7 & 3.98 & 3.93 & 4.00 & 114 & 114 & 114 \\
\hline 8 & 3.21 & 3.14 & 3.30 & 117 & 117 & 117 \\
\hline 9 & 4.04 & 4.04 & 3.96 & 111 & 111 & 111 \\
\hline 10 & 3.28 & 3.45 & 3.46 & 116 & 115 & 115 \\
\hline 11 & 3.33 & 3.54 & 3.47 & $115 a$ & 115a & $112 b$ \\
\hline 12 & 3.95 & 4.04 & 3.94 & 110 & 110 & 110 \\
\hline 13 & 3.82 & 4.01 & 4.02 & 113 & 113 & 113 \\
\hline Spray avg. & 3.65 & 3.73 & 3.70 & 112 & 112 & 112 \\
\hline SE within cultivar among spray & \multirow{2}{*}{\multicolumn{3}{|c|}{$\begin{array}{l}0.088 \\
0.032\end{array}$}} & \multicolumn{3}{|c|}{0.41} \\
\hline SE among spray avg. & & & & & & \\
\hline
\end{tabular}

* Means within cultivar for each variable followed by the same letter or without letters are not different $(p \leq 0.05)$.

† See Table 4 for complete cultivar descriptions.

$\$$ Spray treatments: Gly $=$ glyphosate with ammonium sulfate (AMS) and water; AMS $=$ AMS and water; Water $=$ water alone. 
Table 6. Spray treatment effects on glyphosate-resistant soybean cultivars. Averages of four locations. Nebraska, 1998 and 1999.

\begin{tabular}{|c|c|c|}
\hline \multirow[b]{3}{*}{ Cultivar $\nmid$} & \multicolumn{2}{|c|}{ 2-yr data } \\
\hline & \multicolumn{2}{|c|}{ Yield } \\
\hline & Gly & AMS \\
\hline & \multicolumn{2}{|c|}{$\mathrm{Mg} \mathrm{ha}^{-1}$} \\
\hline $\mathbf{1}$ & $3.75^{*}$ & 3.85 \\
\hline 2 & 3.71 & 3.73 \\
\hline 3 & 3.52 & 3.57 \\
\hline 4 & 3.66 & 3.67 \\
\hline 5 & 3.81 & 3.94 \\
\hline 6 & 3.96 & 3.98 \\
\hline 7 & 3.98 & 3.99 \\
\hline 8 & 3.54 & $\mathbf{3 . 5 3}$ \\
\hline 9 & 3.95 & 3.91 \\
\hline 10 & 3.44 & 3.58 \\
\hline 11 & 3.56 & 3.62 \\
\hline 12 & 3.85 & 3.88 \\
\hline Spray avg. & 3.74 & 3.79 \\
\hline SE within cultivar between spray & \multicolumn{2}{|c|}{0.064} \\
\hline SE between spray avg. & \multicolumn{2}{|c|}{0.163} \\
\hline
\end{tabular}

* Means within cultivar between the two treatments are not different ( $p \leq$ 0.05 ) for any of the cultivars.

† See Table 4 for complete cultivar descriptions.

$\$$ Gly $=$ glyphosate with ammonium sulfate (AMS) and water; AMS = AMS and water.

sons at SCREC where flowering was delayed by glyphosate with AMS and water relative to conventional herbicides (R.W. Elmore, unpublished data, 1997). Flowering was neither affected by the glyphosate nor AMS in the present study (Table 4). However, plant height at physiological maturity in 1999 was reduced by 8 to $9 \mathrm{~mm}$ with glyphosate (Table 4). This finding was consistent across all locations but was not significant in the 2-yr analysis.

\section{Cultivar as Affected by Spray Treatments}

Grain yield of GR cultivars was neither affected by glyphosate at any location (data not shown) nor affected when averaged across locations (Tables 5 and 6). This was true in both the 1- and 2-yr analyses. Likewise, cultivar yield responses were consistent across the spray treatments. Physiological maturity of most of the cultivars was likewise not affected by the spray treatments; however, there were a few differences among some cultivars (Table 5 and 6). For example, physiological maturity of cultivar 11 was delayed with both glyphosate and AMS relative to the water alone treatment (Table 5). No other cultivar was affected in this way. Grain yield was not affected.

\section{CONCLUSIONS}

Although grain yield and plant characteristics varied among cultivars, in most cases they were not affected by glyphosate. Glyphosate did not affect yield of cultivars evaluated and thus did not contribute to yield suppression.

\section{ACKNOWLEDGMENTS}

We thank the Nebraska Soybean Development, Utilization and Marketing Board, who partially supported the research.
Technical support at the various locations were: Clay CenterSharon Hachtel, George Hoffmeister, Jr., Irv Schleufer, Ralph Klein, and Perry Ridgeway; Lincoln-Greg Dorn and John Eis; North Platte-Jeff Goulis; Concord-Lisa Lunz and Ray Brentlinger. We appreciate their efforts!

\section{REFERENCES}

Bennett, A.C., D.R. Shaw, and S.M. Schraer. 1998. Effect of conventional herbicide programs and irrigation on glyphosate-tolerant soybean yield. p. 270-271. In Proc. Southern Weed Science Society. Southern Weed Sci. Soc., Champaign, IL.

Delannay, X., T.T. Bauman, D.H. Beighley, M.J. Buettner, H.D. Coble, M.S. DeFelice, C.W. Derting, T.J. Diedrick, J.L. Griffin, E.S Hagood, F.G. Hancock, S.E. Hart, B.J. LaVallee, M.M. Loux, W.E. Lueschen, K.W. Matson, C.K. Moots, E. Murdock, A.D. Nickell, M.D.K. Owen, E.H. Paschall II, L.M. Prochaska, P.J. Raymond, D.B. Reynolds, W.K. Rhodes, F.W. Roeth, P.L. Sprankle, L.J. Tarochione, C.N. Tinius, R.H. Walker, L.M. Wax, H.D. Weigelt, and S.R. Padgette. 1995. Yield evaluation of a glyphosate-tolerant soybean line after treatment with glyphosate. Crop Sci. 35:1462-1467.

Elmore, R.W., F.W. Roeth, L.A. Nelson, C.A. Shapiro, R.N. Klein, S.Z. Knezevic, and A. Martin. 2001. Glyphosate-resistant soybean cultivar yields compared with sister lines. Agron. J. 93:408-412 (this issue).

Hofer, J.M., D.E. Peterson, W.B. Gordon, S.A. Staggenborg, and D.L. Fjell. 1998. Yield potential and response of glyphosate-resistant soybean varieties to imidazolinone herbicides. p. 25-26. In Proc. North Central Weed Sci. Society. North Central Weed Sci. Soc., Champaign, IL.

Littell, R.C., G.A. Milliken, W.W. Stroup, and R.D. Wolfinger. 1996. SAS system for mixed models. SAS Inst., Cary, NC.

Minor, H. 1998. Performance of GMOs vs. traditional varieties: A southern perspective. p. 1-9. In Proc. of the 28th Soybean Seed Research Conf., Chicago, IL. Dec. 1998. Am. Seed Trade Assoc., Washington, DC.

Moll, S. 1997. Commercial experience and benefits from glyphosate tolerant crops. Brighton Crop Prot. Conf.-Weeds 3:931-940.

National Agricultural Statistics Service. 1999. Crop Production Data [Online]. Available at http://usda.mannlib.cornell.edu/reports/ nassr/field/pcp-bb/1999/crop1099.txt (verified 10 Mar. 2000).

Nelson, K.A., and K.A. Renner. 1999. Weed management in wideand narrow-row glyphosate resistant soybean. J. Prod. Agric. 12: 460-465.

Nelson, L.A., R.W. Elmore, R.N. Klein, and C. Shapiro. 1997. Nebraska soybean variety tests-1997. Nebraska Coop. Ext. E. C. 97 104-A. Univ. of Nebraska, Lincoln.

Nelson, L.A., R.W. Elmore, R.N. Klein, and C. Shapiro. 1998. Nebraska soybean variety tests-1998. Nebraska Coop. Ext. E. C. 98104-A. Univ. of Nebraska, Lincoln.

Nelson, L.A., R.W. Elmore, R.N. Klein, and C. Shapiro. 1999. Nebraska soybean variety tests-1999. Nebraska Coop. Ext. E. C. 99 104-A. Univ. of Nebraska, Lincoln.

Oplinger, E.S., M.J. Martinka, and K.A. Schmitz. 1998. Performance of transgenic soybeans: Northern United States. p. 10-14. In Proc of the 28th Soybean Seed Research Conf., Chicago, IL. Dec. 1998. Am. Seed Trade Assoc., Washington, DC.

Padgette, S.R., K.H. Kolacz, X. Delannay, D.B. Re, B.J. LaVallee, C.N. Tinius, W.K. Rhodes, Y.I. Otero, G.F. Barry, D.A. Eichholtz, V.M. Peschke, D.L. Nida, N.B. Taylor, and G.M. Kishore. 1995 Development, identification, and characterization of a glyphosatetolerant soybean line. Crop Sci. 35:1451-1461.

Rasche, E., and M. Gadsby. 1997. Glufosinate amonium resistant crops: International commercial developments and experiences. Brighton Crop Prot. Conf.-Weeds 3:941-946.

Ritchie, S.W., J.J. Hanway, and H.E. Thompson. 1996. How a soybean plant develops. Spec. Rep. 53. Iowa State Univ. Coop. Ext. Ser., Ames, IA.

U.S. Department of Agriculture Economic Research Service. 1999. Genetically engineered crops for pest management [Online]. Available at http:/www.econ.ag.gov/whatsnew/issues/biotech (verified 10 Mar. 2000) 